\title{
Malignant germ cell tumor of the cervix uteri
}

INSERM

\section{Source}

INSERM. (1999). Orphanet: an online rare disease and orphan drug data base. Malignant germ cell tumor of the cervix uteri. ORPHA:213837

Malignant germ cell tumor of the cervix uteri is an extremely rare uterine neoplasm characterized by a usually polypoid, friable tumor deriving from primordial germ cells located in the uterine cervix. Presentation is non-specific and often includes abnormal vaginal bleeding and/or discharge, a cervical mass protruding from the vagina, abdominal and/or pelvic pain or, less commonly, difficulty passing stool and perianal pain. Various histological subtypes (incl. dysgerminoma, yolk sac tumor, choriocarcinoma and malignant teratoma) are reported. 